\title{
PROTECTOR MECHANISMS OF
} THE ASSOCIATION BETWEEN

\section{GASTROESOPHAGEAL REFLUX DISEASE AND ASTHMA. Experimental study in rats}

\author{
Paula Yuri Sugishita KANIKADAN ${ }^{1}$, Jayme Antonio Aboin SERTIÉ2 \\ Ricardo Martins OLIVEIRA-FILHO² and Wothan Tavares de LIMA²
}

\begin{abstract}
Background - It is well known the association between gastroesophageal reflux disease and asthma. The hyperreactivity of the airways is a characteristic of an asthmatic. Many studies associate the increase of the airways reactivity with gastroesophageal reflux disease. Aim - In this study we have evaluated the effect of the intraluminal exposition to gastric juice of trachea on the reactivity to methacholine from rats submitted to a pulmonary allergic inflammation. Methods - Group of rats were sensitized and challenged with ovalbumin. After 24 hours the animals were sacrificed, and their tracheae were removed to be cultured with gastric juice. The gastric juice was obtained from a donor rat. Subsequently the segments were placed into plastic plates with RPMI-1640 for incubation, under suitable atmosphere and time. After the period of incubation the segments were put into chambers for the analysis of the contractile response to methacholine. Results We observed reduction in the contractile response of trachea cultured with gastric juice from allergic rats. This result was confirmed by the pharmacological treatments with compound $48 / 80$ and dissodium cromoglicate (mast cells blockade), L-NAME (nitric oxide inhibitor, NO), capsaicin (neuropeptides depletion) and indomethacin (ciclooxigenase inhibitor). Conclusions - Our results highlight to the existence of a complex interaction between pulmonary allergy and gastric juice in the airways. The involvement of the non-adrenergic non-cholinergic system, NO, prostanoids and mast cells are directly related to this interaction. We suggest that the reduced contractile response observed in vitro may represent a protector mechanism of the airways. Despite its presence in the human body it can not be observed due to the predominant effects of excitatory the non-adrenergic non-cholinergic system.
\end{abstract}

HEADINGS - Gastroesophageal reflux. Asthma. Bronchial hyperreactivity. Methacholine chloride. Rats.

\section{INTRODUCTION}

Compelling evidence suggests a putative interaction between gastroesophageal reflux disease (GERD) and airways dysfunction ${ }^{(3,9,27)}$. A high prevalence of GERD (around $80 \%$ ) is found in asthmatic patients ${ }^{(29)}$. Generally the worsening of asthma is associated to the presence of GERD. It is characterized by hoarseness, chronic cough, high ventilation and laryngospasm. In addition a vagal reflex or its functional exacerbation are observed after gastric content microaspiration into the airways ${ }^{(1,8,14,28)}$.

Microaspiration in asthmathic subjects might occur due to an abnormal function of the lower esophageal sphincter as a consequence of bronchodilator therapy ${ }^{(18,29)}$. Indeed studies indicate that esophageal tonus is reduced by $\beta$-adrenergic agonists. These drugs facilitate the events of microaspiration ${ }^{(19,22)}$.

Cholinergic innervation and the non-adrenergic non-cholinergic system (NANC system) are the major components of airway tonus ${ }^{(7,12)}$. In fact a number of studies recognizes the role of acethylcholine as well as the neuropeptides and nitric oxide (NO). They are modulators of airway reactivity in experimental asthma model ${ }^{(5,16)}$. The involvement of cholinergic and NANC system is not yet fully understood in the interaction between airways allergic diseases and GERD ${ }^{(1)}$.

One of the major cells involved in the allergic inflammation are the mast cells. Once activated release a number of mediators ${ }^{(11)}$, and after esophageal acidification the number of these cells has been reported to reduce ${ }^{(2)}$. The aspiration of gastric content, as observed in GERD, is a potential factor for mast cell activation, with possible changes in airways reactivity. In the present study we have examined the effects of the contact of the airways with gastric juice (GJ) on the reactivity of isolated trachea from rats submitted to pulmonary allergic inflammation.

This article was performed in the Department of Pharmacology, Institute of Biomedical Sciences, University of São Paulo, São Paulo, SP, Brazil.

${ }^{1}$ Department of Public Health Practice, Faculty of Public Health, University of São Paulo; ${ }^{2}$ Department of Pharmacology, Institute of Biomedical Sciences, University of São Paulo, São Paulo, SP, Brazil.

Correspondence: Dr. Paula Yuri Sugishita Kanikadan - Rua Monte Caseros, 313 - apt. 41 - Vila Gomes - 05590-130 - São Paulo, SP, Brazil. 


\section{METHODS}

\section{Animals}

Male Wistar rats (180-200 g) from our departmental facilities were used. They were housed in groups of five per cage in controlled temperature $\left(21-23^{\circ} \mathrm{C}\right)$ and $12 \mathrm{~h}$ light/dark cycle conventional conditions, with free access to food and water. Experiments were carried out in compliance with the guidelines of the Ethical Principles in Animal Research adopted by Brazilian College of Animal Experimentation (COBEA) (protocol no. 107).

\section{Gastric juice collection}

Briefly under anesthesia the stomach of the rat was localized through laparotomy. In order to avoid the transit of gastric content the pilore was occluded using suture nylon 4.0. Thereafter the organ was replaced into the peritoneal cavity. Elapsed 2 hours the rats were killed by deep anesthesia and the stomach was removed and placed in a Petri's dish. After a small incision the lumen of stomach was exposed and the GJ was collected using a plastic syringe $(5 \mathrm{~mL})$. The volume of GJ collected $( \pm 3 \mathrm{~mL})$ was centrifuged at $1500 \mathrm{rpm}$ during $15 \mathrm{~min}$ and the $\mathrm{pH}$ determined using a phMeter measured ${ }^{(26)}$.

\section{Sensitization and in vivo antigen challenge}

Groups of rats were sensitized by intra-peritoned (IP) injection of a suspension of $10 \mu \mathrm{g}$ of ovalbumin (OVA) with $10 \mathrm{mg}$ of aluminum hydroxide (day 0). One week later (day 7) the rats were boosted subcutaneously with $10 \mu \mathrm{g}$ of OVA dissolved in saline and thereof labeled as "allergic". At day 14 rats were subjected to a single exposure of aerosolized OVA (1\% in PBS solution) for 15 min using an ultrasonic nebulizer device (Icel ${ }^{\circledR}$, São Paulo, Brazil) coupled to a plastic inhalation chamber $(18.5 \mathrm{~cm} \times 18.5$ $\mathrm{cm} \times 13.5 \mathrm{~cm}$ ). According to the manufacturers the nebulizer produces aerosol particles with a mean size of $0.5-1.0 \mu \mathrm{m}$. The experiments were performed 1 day after antigen challenge and the animals were exsanguinated under deep chloral hydrate anesthesia (400 mg/kg, IP) by sectioning the abdominal aorta.

\section{Intraluminal exposure of tracheal segments with gastric juice}

Tracheal segments of killed rats were isolated 1 day after antigen challenge. The thorax was opened and the trachea was removed into Petri's dish containing Krebs-Henseileit solution. The tracheal segments were clean up of adjacent connective tissue and filled with $20 \mu \mathrm{L}$ of GJ $(\mathrm{pH}=1-2)$. As control tracheal segments were filled with similar volume of saline solution $(0,9 \%)$. In order to avoid the leak of the filled material, the anterior and posterior end of the segments were tightly closed using a nylon suture 4.0. Tracheal segments filled with GJ were added in the 24- wells plastic plates containing $1,5 \mathrm{~mL}$ of RPMI-1640 and maintained during $3 \mathrm{~h}$ in $5 \% \mathrm{CO}_{2} /$ $95 \% \mathrm{O}_{2}$ atmosphere $\left(37^{\circ} \mathrm{C}\right)$.

\section{In vitro study of airways reactivity}

After the incubation period the tracheae segments were removed from the plates and introduced into isolated organ chambers containing Krebs-Henseleit solution with $95 \% \mathrm{O}_{2}$ and $5 \% \mathrm{CO}_{2}$ at $37^{\circ} \mathrm{C}$ to evaluate isometrically the responses to methacholine. Cumulative concentration-effect curves to methacholine were done, using a data register system (MacLab), and acquisition, stockage and data were analysed (software MLS301). All the Emax were expressed as g/100 mg weight.

\section{Pharmacological treatments}

The animals were submitted to pharmacological treatments to assess the role of specific drugs acting on the reactivity of tracheal segments.

Mast cells blockade. At the 10th day of sensitization, groups of rats received, for 5 days, IP injection in increasing doses $\left(1-5 \mathrm{mg} / \mathrm{kg}\right.$ ) of compound $48 / 80^{(25)}$. This compound acts selectively on connective tissue mast cells.

Another group of rats was treated with the mast cell stabilizer sodium cromoglycate by aerosol during 5 consecutive days $(2.5 \mathrm{mg} / \mathrm{mL}$ for 15 minutes)

Nitric oxide inhibitor. We treated groups of animals with L-NAME (30 mg/kg, IV, Sigma), 30 minutes before the antigen challenge.

Arachidonic acid metabolite inhibitor. Rats were treated with indomethacin ( $4 \mathrm{mg} / \mathrm{kg}$, IV, Sigma), 30 minutes before the antigen challenge to investigate the role of cyclooxygenasederived mediators.

Neuropeptides depletion. Rats were treated with capsaicin $\left(20+30+50 \mathrm{mg} / \mathrm{kg}\right.$, s.c.) during 3 days $^{(6)}$. After 14 days, the experiments were conduced.

\section{Statistical analysis}

The data were analyzed by one-way analysis of variance (ANOVA) followed by Student $t$ test for non parametric samples, using GraphPad Software V.2.01, GraphPad Instat-tm (1990-1993). The results were expressed as medium \pm SEM from 5 to 8 animals $(P<0.05$ were considered statistically significant).

\section{RESULTS}

\section{Reactivity to methacholine}

The analysis of the reactivity to methacholine of tracheal tissues submitted to GJ during 3 hours collected from allergic rats (OVA/OVA + GJ group) is the object of our study.

Taking this into account tracheal segments cultured with GJ from allergic rats developed a significant hyporesponsiveness to methacholine $(\mathrm{Emax}=10.50 \pm 1.20, \mathrm{OVA} / \mathrm{OVA}+\mathrm{GJ}$ group $)$ when compared to reactivity of tracheal segments of allergic rats non subjected to contact with GJ (Emax $=16.30 \pm 0.80$, OVA/OVA group-control) (Figure 1).

Similarly tracheal segments from rats of the naïve group (Emax $=14.70 \pm 0.60$, non manipulated group) did not show differences on the reactivity to methacholine in comparison to the OVA/OVA + GJ group. The same situation was observed in the reactivity of tracheae from the group exposed only to GJ, non allergic (Emax $=14.31 \pm 1.53$, GJ group) when compared to the OVA/OVA + GJ group (Figure 1). This experiment was carried on to assess the role of GJ itself. Both of the groups, naïve and GJ, have worked as control. 


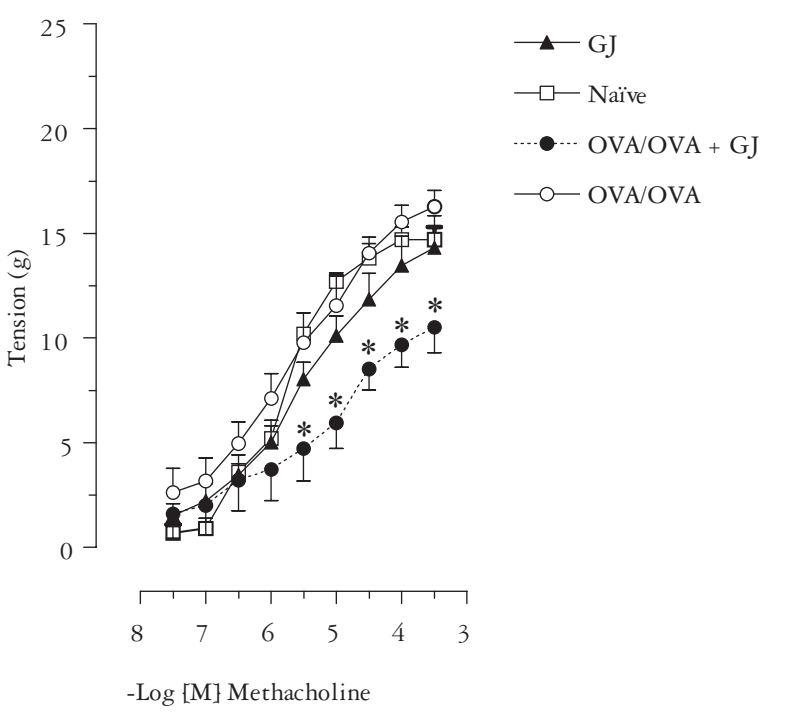

FIGURE 1. Concentration-effect curves of proximal trachea from allergic and non-allergic rats intraluminally exposed to GJ. The trachea of the animals (OVA/OVA+GJ or GJ groups) were submitted to the intraluminal exposition to GJ. A group was sensitized and challenged with ovalbumin (OVA/OVA). The naïve group represents rats which were sacrificed and their tracheae were submitted to the analysis of the contractile response. Crescent concentrations of methacholine expressed in molar were used. The data were expressed as the mean \pm SEM of six-eight animals. $* P<0.05$ compared with GJ, naïve and OVA/OVA groups

\section{Pharmacological treatments}

Considering the hyporesponsiveness of the tissue we have described the action of each drug on the reversion of this diminished reactivity to methacholine. All of these treatments were conduced in animals submitted to a pulmonary allergic inflammation, that is, the rats were allergic.

Figure 2 shows the reactivity to methacholine of tracheal segments of allergic rats previously treated with indomethacin (4 mg/kg, intravenous (IV)) and exposed to GJ during 3 hours (GJ + indomethacin group). This treatment significantly increased the tracheal reactivity to methacholine $(E \max =14.50 \pm 1.42)$ relative to trachea from allergic rats exposed to GJ but non treated with indomethacin $(\operatorname{Emax}=9.91 \pm 1.03, \mathrm{OVA} / \mathrm{OVA}+$ GJ group).

L-NAME treatment of allergic rats $($ Emax $=19.62 \pm$ 1.61, GJ + L-NAME group) reverted the hyporesponsiveness to methacholine of tracheal segments exposed to GJ when compared to allergic rats non treated $($ Emax $=10.60 \pm 0.80$, OVA/OVA + GJ group) (Figure 3).

Tracheal segments of allergic rat treated in vivo with capsaicin were cultured with GJ (GJ + capsaicin group). The contractile response to methacholine were not affected $($ Emax $=9.12 \pm$ 0.68 ) when compared to the reactivity of tracheae from non treated but allergic rat $(\mathrm{Emax}=9.96 \pm 0.37, \mathrm{OVA} / \mathrm{OVA}+\mathrm{GJ}$ group) (Figure 4).

Finally the interaction of mast cells and GJ on tracheal reactivity was also evaluated. Groups of allergic rats were treated with

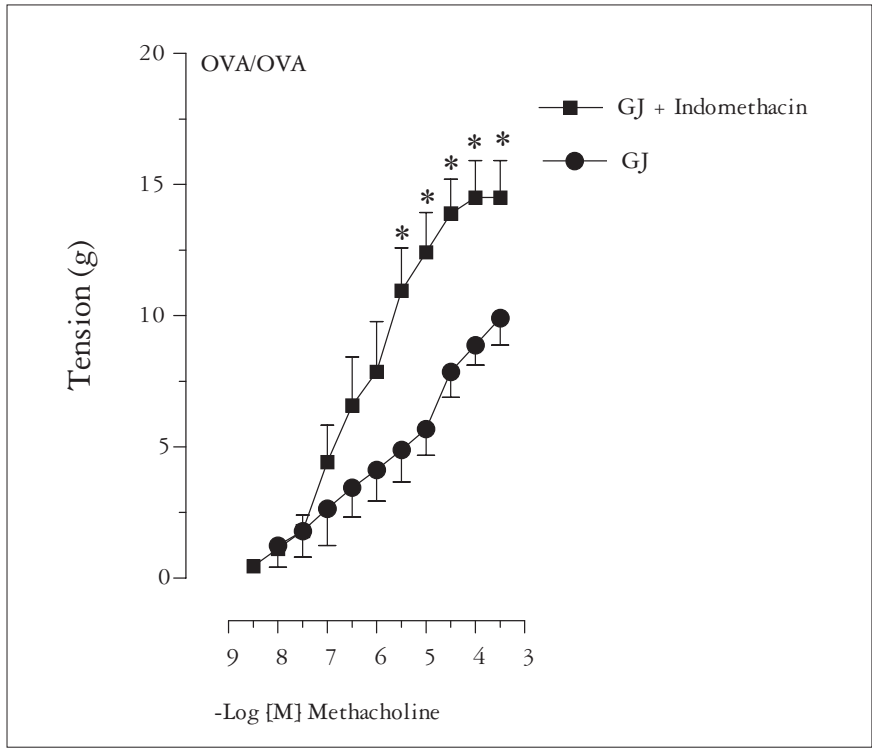

FIGURE 2. Concentration-effect curves of proximal trachea from allergic rats treated with indomethacin. The animals were submitted to the treatment with indomethacin and their tracheae exposed intraluminally to GJ. A control group was sensitized and challenged with ovalbumin and its trachea incubated with GJ. Crescent concentrations of methacholine expressed in molar were used. The data were expressed as the mean \pm SEM of seven animals. $* P<0.05$ compared with GJ group

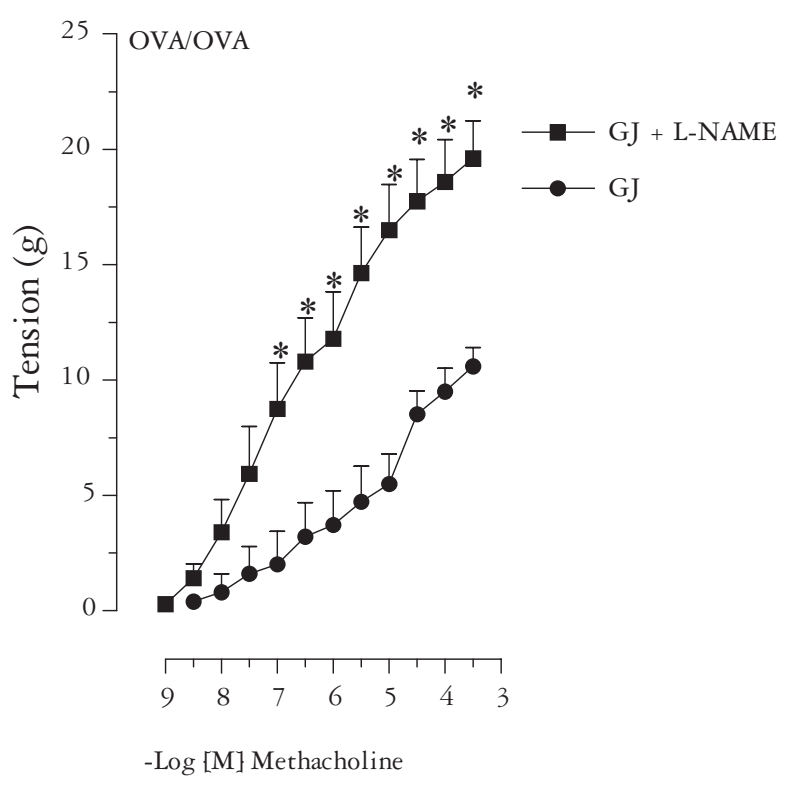

FIGURE 3. Concentration-effect curves of proximal trachea from allergic rats treated with L-NAME. The animals were submitted to the treatment with L-NAME and their tracheae exposed intraluminally to GJ. A control group was sensitized and challenged with ovalbumin and its trachea incubated with GJ. Crescent concentrations of methacholine expressed in molar were used. The data were expressed as the mean \pm SEM of six-eight animals. $* P<0.05$ compared with $\mathrm{GJ}$ group 


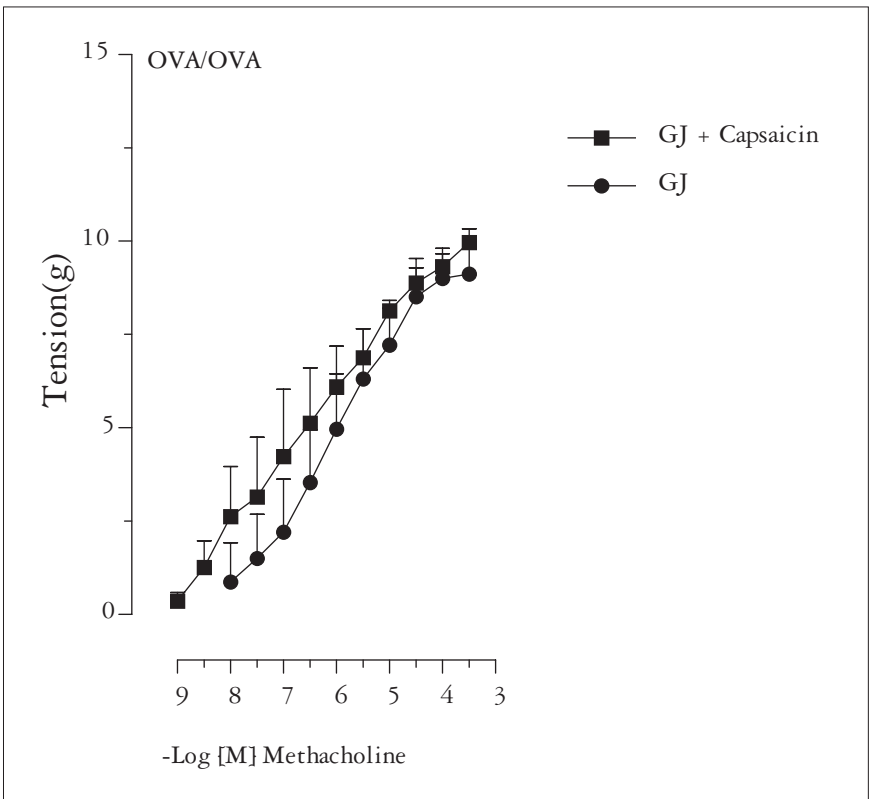

FIGURE 4. Concentration-effect curves of proximal trachea from allergic rats treated with capsaicin. The animals were submitted to the treatment with capsaicin and their tracheae exposed intraluminally to GJ. A control group was sensitized and challenged with ovalbumin and its trachea incubated with GJ. Crescent concentrations of methacholine expressed in molar were used. The data were expressed as the mean \pm SEM of seven animals. $* P<0.05$ compared with GJ group

compound 48/80 (Figure 5) and sodium cromoglicate (Figure 6). At Figure 5 tracheal segments of compound 48/80-treated from allergic rats when cultured with GJ have showed a significant increase of the contractile response $(\mathrm{Emax}=17.15 \pm 1.44$, GJ $+\mathrm{C} 48 / 80$ group) as compared with the respective control group of allergic rats non treated $($ Emax $=11.00 \pm 0.87$, OVA/OVA + GJ group). Similar results were observed in the contractile response of tracheae from allergic rats pre-treated with sodium cromoglicate $($ Emax $=14.64 \pm 1.26, \mathrm{GJ}+$ cromoglicate group $)$ when compared to the responses from segments submitted to GJ exposition from allergic rats cromoglicate-free $(\operatorname{Emax}=9.90 \pm 1.05$, OVA/OVA + GJ group) (Figure 6).

\section{DISCUSSION}

We had developed herein an experimental model which mimicked the in vivo effects of the airways reactivity on asthma after their exposition to gastric content in events of GERD or microaspiration. The incubation with GJ is due to the existence of other components besides chloridric acid. The use of this substance ordinary occurs in in vivo studies ${ }^{(20,34)}$. Our data have showed that the intraluminal exposition with GJ of trachea segments from allergic rats caused in vitro hyporesponsiveness of the tissue to a cholinergic stimulus (Figure 1).

GJ acts as an irritant of the airways. Indeed the initial expectance was that GJ would increase the contractile response to methacholine of trachea from allergic rats. The augment of the reactivity is a resulting from the vagal reflex response

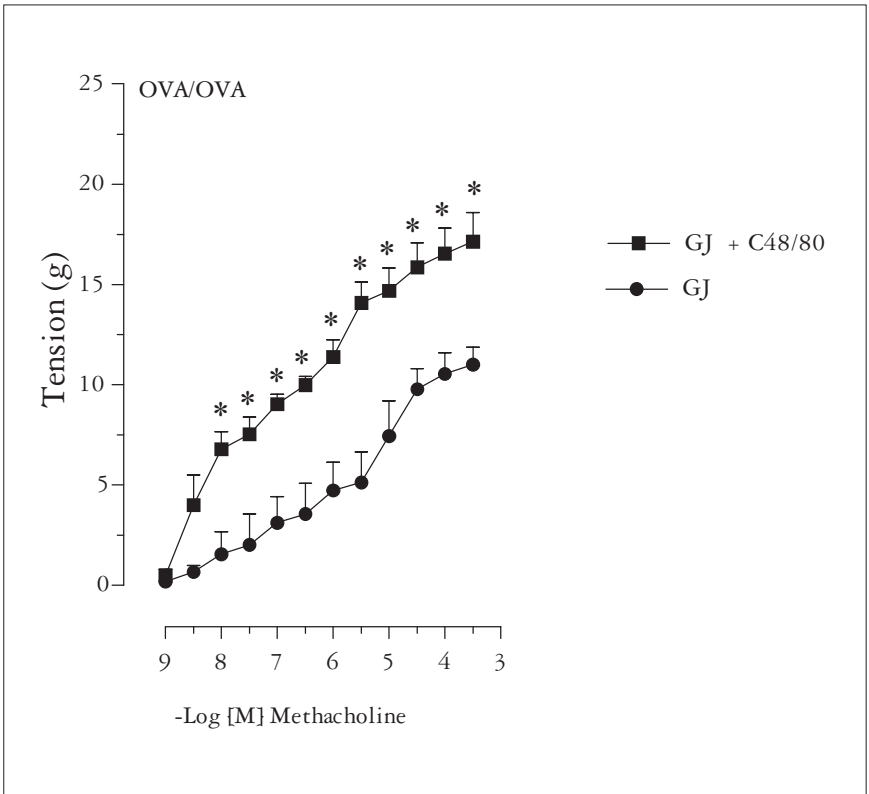

FIGURE 5. Concentration-effect curves of proximal trachea from allergic rats treated with compound $48 / 80$. The animals were submitted to the treatment with compound $48 / 80$ and their tracheae exposed intraluminally to GJ. A control group was sensitized and challenged with ovalbumin and its trachea incubated with GJ. Crescent concentrations of methacholine expressed in molar were used. The data were expressed as the mean $\pm \mathrm{SEM}$ of five-seven animals. $* P<0.05$ compared with GJ group

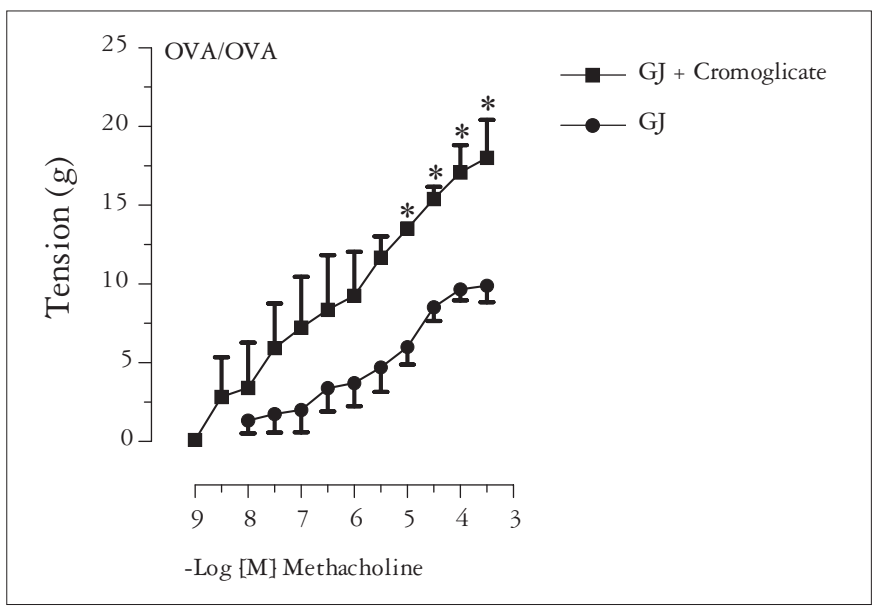

FIGURE 6. Concentration-effect curves of proximal trachea from allergic rats treated with sodium cromoglicate. The animals were submitted to the treatment with cromoglicate and their tracheae exposed intraluminally to GJ. A control group was sensitized and challenged with ovalbumin and its trachea incubated with GJ. Crescent concentrations of methacholine expressed in molar were used. The data were expressed as the mean $\pm \mathrm{SEM}$ of five-seven animals. $* P<0.05$ compared with GJ group

generated by the esophagus after its exposition to acid ${ }^{(13,30)}$. The local release of neuropeptides due to the acidification of the airways also affects the bronchial smooth muscle through the generation of bronchoconstriction and hyperreactivity ${ }^{17}$, 
30). Taking these aspects into account our studies in vitro have additional significance. It is acceptable to suppose that mediators may be implicated in the control of the trachea reactivity after bronchoprovocation and contact with GJ, once the allergic reaction is a multimediated process.

The reduced reactivity might involve the NANC system as the potential modulator of the contractile response when the airways were exposed to GJ. This system releases the neuropeptides neurokinin A, substance $\mathrm{P}, \operatorname{VIP}^{(7,12,15,17)}$ as well as $\mathrm{NO}^{(10,15)}$. It has two functional components, the inhibitory NANC (bronchodilation) and the excitatory NANC (bronchoconstriction). Even though this system participates in the mechanisms which account for hyperreactivity on asthma ${ }^{(5)}$, the participation of NANC in the modulation of the reactivity of the airways in the presence of GERD might protect the airways against the bronchoconstriction. In this way we have observed that the treatment with capsaicin, a drug that depletes neuropeptides in sensory nerve endings ${ }^{(6)}$, did not change the reactivity of trachea from allergic rats (Figure 4). A possible interpretation of these data is that in experimental conditions, which lead to the reduction of substance $\mathrm{P}$, there was a decrease in the contractile response despite the stimuli of NANC by GJ. We suggest that in trachea cultured with GJ from capsaicin-treated rats occurs the release of some relaxing factor responsible for the relaxation of the smooth muscle which modulates the effects of methacholine, that is, GJ exerts direct activation on NANC system, releasing neuropeptides. Moreover GJ can active directly the mast cells, and they active $\mathrm{NANC}^{(33)}$.

Interestingly the treatment with NO synthesis inhibitor, L-NAME (non-specific inhibitor), have enhanced the contractile response to methacholine (Figure 3). It is well known that NO exerts potent relaxing effects in the airways ${ }^{(4,21)}$. We suggest that the allergic stimuli associated to GJ exposure induces NO generation through the NANC pathway. There are important effects of GJ on mast cells as well. These cells could stimulate the NANC system once they were activated because of the allergic stimuli in addition to the action of GJ. It cooperates for higher expression of the inhibitory NANC system.

Alternatively there are potential candidates to the modulation of the relaxation of the airways smooth muscle, apart from NO and VIP. Prostanoids are also considered relaxing mediators of the airways. In fact $\mathrm{PGE}_{2}$ is an important mediator of the relaxing contractile response of the airways ${ }^{(23)}$. Furthermore its involvement with NANC has also been reported ${ }^{(32)}$. We have found an increase in the contractile response of trachea when we treated immunized and challenged animals with indomethacin (inhibitor of ciclooxigenase, Figure 2). Under cyclooxigenase blockade the incubation of the tissues with GJ have released substance $\mathrm{P}$ (responsible for the contractile effects on airways smooth muscle) but not relaxing prostanoids. This is reasonable once there is a correlation between the effects of capsaicin and the release of $\mathrm{PGE}_{2}{ }^{(31)}$. According to studies that have been conduced in intrapulmonary bronchi of rats the activation of $\mathrm{C}$ fibers leads to the release of substance $P$. This substance activates the $\mathrm{NK}_{1}$ receptors on airways epithelium and causes subsequent generation of inhibitory prostanoids. The relaxing of the muscle would be one of the results ${ }^{(21,32)}$.

Lastly it is important to consider that mast cells play an important role in the modulation of the effects of GJ in asthmatic patients and GERD subjects once these cells release NO and neuropeptides - NO and substance $\mathrm{P}$ act through an autocrine pathway inside these cells ${ }^{(33)}$. Taking it into account we have observed a reversion of the hyporesponsiveness in the treatment of allergic rats with compound 48/80 (Figure 5). This compound exhausts connective mast cells. It is possible that the antigen (ovalbumin) have not found activated mast cells in a sufficient number and the lumen of the trachea have been stimulated only by GJ. Indeed studies that have been conduced by BARCLAY et al. ${ }^{(2)}$ indicated that the acidification of esophagus degranulates mast cells. Similarly the treatment with sodium cromoglicate reversed the diminished reactivity of trachea (Figure 6). This drug stabilizes the mast cells membrane by blocking the degranulation of connective mast cells ${ }^{(24)}$. Thus we infer that GJ associated to inflammation produces mediators responsible for the relaxing of trachea muscle.

This in vitro study indicates a complex interaction between inflammation and GJ in the airways. The action of mast cells, NANC system, NO and prostanoids represent this interaction. Altogether our results suggest that the reduced contractile response that has been detected in this study may represent a protective mechanism of the airways. Even though present this hyporesponsiveness is not observed in vivo due to the prominent effects of the excitatory NANC system.

\section{ACKNOWLEDGEMENTS}

We are grateful to the colleagues of laboratory Adriana Lino dos Santos Franco, Zilma Lúcia da Silva e Guiomar Wiezel for the technical support in this research. This study was supported by "Coordenação de Aperfeiçoamento de Pessoal de Nível Superior” (CAPES). 
Kanikadan PYS, Sertié JAA, Oliveira-Filho RM, Lima WT. Mecanismos protetores: doença do refluxo gastroesofágico e asma. Estudo experimental em ratos. Arq Gastroenterol. 2008;45(3):243-8.

RESUMO - Racional - É bem estabelecida a relação entre a doença do refluxo gastroesofágico e a asma. A hiperreatividade das vias aéreas é uma das características que o indivíduo asmático desenvolve e diversos estudos associam o aumento da reatividade das vias aéreas com o refluxo gastroesofágico. Objetivo - Avaliar a reatividade à metacolina de traquéia exposta intraluminalmente ao suco gástrico de ratos submetidos a inflamação alérgica pulmonar. Métodos - Grupos de ratos foram sensibilizados e broncoprovocados com ovoalbumina. Após 24 horas, os animais foram sacrificados e a traquéia removida para preenchimento de seu lúmen com suco gástrico obtido de um animal doador. A seguir, os segmentos foram colocados em placas plásticas com RPMI-1640 e mantidos em estufa por 3 horas em condições ambientais adequadas. Após o tempo de incubação, os fragmentos foram montados em cubas de vidro para órgão isolado para registro isométrico de contração, através da construção de curvas concentração-efeito à metacolina. Resultados - Observou-se redução da resposta contrátil em traquéia exposta ao suco gástrico proveniente de ratos alérgicos. Os tratamentos farmacológicos com composto 48/80 e cromoglicato de sódio (bloqueio de mastócitos), L-NAME (inibidor de óxido nítrico, NO), capsaicina (depleção de neuropeptídios) e indometacina (inibidor da ciclooxigenase) corroboraram esta observação. Conclusões - Os resultados apontam para a existência de complexa interação entre a alergia pulmonar e o suco gástrico nas vias aéreas, com o envolvimento do sistema não-adrenérgico não-colinérgico, NO, prostanóides e mastócitos. À luz das evidências in vivo sobre a hiperreatividade das vias aéreas na associação asma e refluxo gastroesofágico, sugere-se que a reduzida resposta contrátil detectada in vitro pode representar um mecanismo protetor das vias aéreas. A despeito de sua presença, esta redução pode não ser observada in vivo devido à proeminência dos efeitos do sistema não-adrenérgico não-colinérgico excitatório.

DESCRITORES - Refluxo gastroesofágico. Asma. Hiper-reatividade brônquica. Cloreto de metacolina. Ratos.

\section{REFERENCES}

1. Astarita C, Gargano D, Cutajar M, Napolitano A, Manguso F, Abbate GF. Gastroesophageal reflux disease and asthma: an intriguing dilemma. Allergy. 2000;55:52-5.

2. Barclay RL, Dinda PK, Morris GP, Paterson WG. Morphological evidence of mast cell degranulation in an animal model of acid-induced esophageal mucosal injury. Dig Dis Sci. 1995;40:1651-8.

3. Barish $\mathrm{CF}, \mathrm{Wu} \mathrm{WC}$, Castell DO. Respiratory complications of gastroesophageal reflux. Arch Intern Med. 1985;145:1882-8.

4. Barnes PJ, Liew FY. Nitric oxide and asthmatic inflammation. Immunol Today. 1995; 16:128-30

5. Barnes PJ. Neurogenic inflammation in the airways. Resp Physiol. 2001;125 145-54

6. Calatayud S, Barrachina MD, García-Zaragozá E, Quintana E, Esplugues JV. Endotoxin inhibits gastric emptying in rats via a capsaicin-sensitive afferent pathways. Naunyn Schmiedebergs Arch Pharmacol. 2001;363:276-80.

7. Canning BJ, Fischer A. Neural regulation of airway smooth muscle tone. Respir Physiol. 2001;125:113-27.

8. Cuenca-Abente F, Faerberg A, Marty PF, Corti R. Síntomas respiratorios asociados a la enfermedad por reflujo gastroesofágico: diagnóstico y tratamiento. Acta Gastroenterol Latinoam. 2006;36:42-50.

9. De Giorgi F, Palmiero M, Espósito I, Mosca F, Cuomo R. Pathophysiology of gastrooesophageal reflux disease. Acta Otorhinolaryngol Ital. 2006;26:241-6.

10. Fischer A, Folkers G, Geppetti P, Groneberg DA. Mediators of asthma: nitric oxide Pulm Pharmacol Ther. 2002;15:73-81.

11. Galli SJ, Kalesnikoff J, Grimbaldeston MA, Piliponsky AM, Williams CM, Tsai M Mast cells as "tunable" effector and immunoregu-latory cells: recent advances. Annu Rev Immunol. 2005;23:749-86.

12. Groneberg DA, Springer J, Fischer A. Vasoactive intestinal polypeptide as mediator of asthma. Pulm Pharmacol Ther. 2001;14:391-401.

13. Harding SM. GERD, airway disease, and the mechanisms of interaction. In: Stein MR, editor. Gastroesophageal reflux disease and airway disease: lung biology in health and disease. New York: Marcel Dekker; 1999. p.139-78.

14. Jiang SP, Huang LW. Role of gastroesophageal reflux disease in asthmatic patients. Eur Rev Med Pharmacol Sci. 2005;9:151-60

15. Joos GF, Germonpre PR, Pauwels RA. Neural mechanisms in asthma. Clin Exp Allergy. 2000;30(Suppl 1):60-5

16. Kadota H, Kuwahara M, Nishibata R, Mikami H, Tsubone H. Effect of M2 and M3 muscarinic receptors on airway responsiveness to carbachol in bronchialhypersensitive (BHS) and bronchial-hyposensitive (BHR) guinea pigs. Exp Anim. 2001;50:49-58.

17. Kraneveld AD, Nijkamp FP. Tachykinins and neuro-immnue interactions in asthma. Int Immunopharmacol. 2001;133:1629-50.
18. Lagergren J, Bergstrom R, Adami HO, Nyren O. Association between medications that relax the lower esophageal sphincter and risk for esophageal adenocarcinoma. Ann Intern Med. 2000;1:227-9.

19. Lazenby JP, Harding SM. Chronic cough, asthma, and gastroesophageal reflux. Curr Gastroenterol Rep. 2002;2:217-23.

20. Lopes FDTQS. Efeito pulmonar da instilação de ácido clorídrico na traquéia e no terço inferior do esôfago: um estudo experimental em cobaias anestesiadas [dissertation] São Paulo: Instituto de Ciências Biomédicas, Universidade de São Paulo; 2000.

21. Manzini S. Bronchodilation by tachykinins and capsaicin in the mouse main bronchus Br J Pharmacol. 1992;105:968-72.

22. Moote DW, Lloyd DA, McCourtie DR, Wells GA. Increase in gastroesophageal reflux during methacholine-induced bronchospasm. J Allergy Clin Immunol. 1986;78:619-23.

23. Pavord ID, Wong CS, Williams J, Tattersfield AE. Effect of inhaled prostaglandin E2 on allergen-induced asthma. Am Rev Respir Dis. 1993;148:87-90.

24. Pearce FL. Functional differences between mast cells from various locations. In: Befus AD, Bienenstock J, Denburg JA, editors. Mast cell differentiation and heterogeneity. New York: Raven; 1986. p. 215.

25. Riley F, West GB. Tissue mast cells: studies with a histamine-liberator of low toxicity (compound 48/80). J Pathol Bacteriol. 1955;69:269-82.

26. Sertié JAA, Carvalho JCT, Panizza S. Antiulcer activity of the crude extract from the leaves of Casearia sylvestris. Pharmaceutical Biology. 2000;38:112-9.

27. Shaker R. Airway protective mechanisms: current concepts. Dysphagia. 1995;10:216-27.

28. Sontag S, O'Connell S, Greenlee H, Schnell T, Chintam R, Nemchausky B, Chejfec G, Van Drunen M, Wanner J. Is gastroesophageal reflux a factor in some asthmatics? Am J Gastroenterol. 1987;82:119-26.

29. Sontag SJ, O'Connell S, Khandelwal S, Miller T, Nemchausky B, Schnell TG, Serlovsky R. Most asthmatics have gastroesophageal reflux with or without bronchodilator therapy. Gastroenterology. 1990;99:613-20.

30. Stein MR. Possible mechanisms of influence of esophageal acid on airway hyperrresponsiveness. Am J Med. 2003;115:55s-9s.

31. Szarek JL, Zhang JZ, Gruetter CA. Mechanisms of 5-hydroxytryptamine-induced contraction of isolated rat intrapulmonary bronchi. Pulm Pharmacol. 1995;8:273-81.

32. Szarek JL, Spurlock B, Gruetter CA, Lemke S. Substance P and capsaicin release prostaglandin E2 from rat intrapulmonary bronchi. Am J Physiol. 1998;L1006-12.

33. Takeuchi K, Kato S, Abe Y, Kinoshita M, Tsuchimoto M. Nitric oxide, histamine, and sensory nerves in the acid secretory response in rat stomach after damage. J Clin Gastroenterol. 1997;25(Suppl 1):s39-s47.

34. Tuchman DN, Boyle JT, Pack AI, Scwartz J, Kokonos M, Spitzer AR, Cohen S Comparison of airway responses following tracheal or esophageal acidification in the cat. Gastroenterology. 1984;87:872-81.

Recebido em 5/11/2007 Aprovado em 30/11/2007 